\title{
Koskenlaskua työyhteisössä
}

\author{
TUULIKKI VENNINEN
}

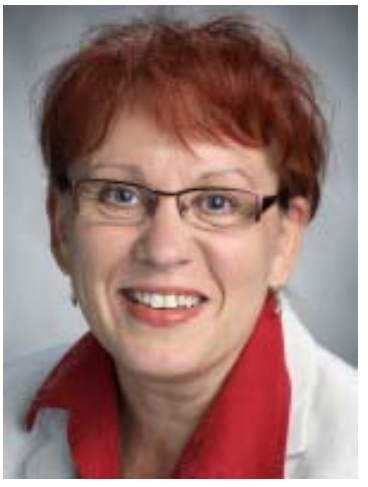

Seison joen rantatörmällä ja tarkkailen sen näennäisen tyyntä pintaa. Kohta olen työntävä kanoottini sen matkaan. Pitkään toiminut työyhteisö on kuin joki, joka on muovannut uomansa ainutlaatuiseksi. Sen kulttuuri on syntynyt aikojen saatossa eikä sitä käy hetkessä muuttaminen, ei edes sen omien jäsentensä taholta. Pinnan alla väreilee pyörteitä, jotka on kohdattava kunnioittaen niiden olemassaoloa, muuten matkaajan kanootti voi karahtaa kiville.

"Yhteisen suunnan etsiminen, hyvään nykyhetkeen pyrkiminen ja jännitteiden hallinta ovat jatkuvia prosesseja, jotka painottuvat työyhteisön eri tilanteissa eri tavoin", kirjoittaa Tuulikki Venninen.

\section{Palautteen merkityksen muutos}

Kun työyhteisössä tehdään työviihtyvyyteen tai osaamiseen liittyvä kartoitus, nousee yleensä esille työntekijöiden kokemukset riittämättömästä omaa työtä koskevasta palautteesta. Kukapa meistä ei saisi kaivattua tyydytystä, jos esimies tai kollegat pysähtyisivät analysoimaan omaa osaamistamme, edellyttäen tietenkin, että se tapahtuisi rakentavassa hengessä.

Nykyajan työyhteisöissä palautteen jakaminen ei voi jäädä vain johtajien varaan. He eivät ole niitä, jotka parhaiten näkevät työntekijöiden työskentelyn arjen konkreettisissa tilanteissa. Jos heillä on paljon alaisia, kuten usein on, heidän on mahdotonta kyetä antamaan konkreettista yksilöllistä palautetta alaisilleen yksinkertaisesti siksi, etteivät työskentele näiden kanssa samoissa tehtävissä. Kollegoiden tuki palautteen muodossa tulee tärkeäksi. Itse näen, että työtoverit jakavat nytkin palautetta jokaisella työpaikalla, mutta usein niin kiertoteitse ja epämääräisesti, ettei sitä ymmärretä palautteeksi. Yksi jakaa palautetta rivien välistä, toinen paiskomalla ovia ja kolmas ilmeiden ja eleiden välityksellä, joista ei edes itse ole tietoinen. Jos mahdollisimman moni tekisi sen selkeästi, rohkeasti ja arvostavasti, lisääntyisi yhteenkuuluvuuden tunne ja kiinnostus sekä oman että kollegoiden työn kehittämiseen. Niin tapahtui ainakin omassa tutkimuksessani.
Palautteen behavioristiset lähtökohdat $(\mathrm{R}>\mathrm{S}>$ O) ovat vuosikymmenten saatossa muuttuneet. Behavioristisen näkökulman ulkoa päin tapahtuva ohjaus on vaihtunut osallistamisen korostamiseen. Sosiokonstruktivismi painottaa kommunikoinnin merkitystä ajatusten jakamisessa ja uuden tiedon tuottamisessa. Uudet näkökulmat ja tulkinnat erilaisille asioille syntyvät yhteisissä keskusteluissa. Palautteen antaja avaa keskustelun tuomalla sanallisesti näkyviin oman käsityksensä näkemästään.

Soili Keskinen (2005) on tuonut Suomeen käsitteen alaistaidoista. Keskinen itsekin tuo esille, että käsite on ongelmallinen siihen liittyvien mielikuvien vuoksi, mutta parempaakaan ei suomen kielessä ole hänen mukaansa tarjolla. Alaistaidot käsittävät suurta vastuuta työtovereista, myös heidän oppimisensa edistämisestä ja taitojensa kartuttamisesta. Näiden taitojen kehittyminen ei ole ainoastaan esimiehen ja alaisen välinen asia, vaan suuressa määrin myös alaisten keskinäinen asia (Keskinen 2005, 21, 84). Jalava (2001, 38-39) viittaa substituuttiteoriaan, kun tuo esille monien eri tekijöiden johtajuutta korvaavat mahdollisuudet. Työntekijät tarvitsevat tukea ja ohjausta, mutta mitkään tutkimukset eivät ole osoittaneet, että tämän on tapahduttava vain esimiehen kautta. Taitavassa palautteen antamisessa ja sen vastaanottamisessa pätevät samat asiat kuin hyvässä vuorovaikutuksessa (ks. Venninen 2007, 238-241). 
Palautteen jakaminen on osa niitä alaistaitoja, jotka ovat työyhteisössä kaikkien vastuulla. On hyvä muistaa, että jokainen palaute on ainoastaan yhden henkilön mielikuva / käsitys tietystä asiasta. Onkin tärkeää, että palautetta saadaan monista eri lähteistä, niiden pohjalta vastaanottaja peilaa käsitystään omasta ammattitaidostaan. Myös palautteen vastaanottajan kommentit voivat avata palautteen antajan silmiä ja hän saattaa muuttaa käsitystään aiemmasta.

\section{Koskenlaskuun valmistautumassa}

Tutkimukseni tehtävänä oli selvittää, millaisia mahdollisuuksia yhteisöllisen palautteen avulla on lisätä työyhteisön jäsenten tietoisuutta omasta ammatillisesta osaamisestaan. Päiväkodin työntekijät ovat koulutuksestaan ja työkokemuksestaan johtuen erilaisilla ammatillisilla tasoilla, joten työyhteisössä on hyvä pyrkiä kehittämään ammatillista osaamista jokaisen yksilöllisistä lähtökohdista, mutta yhdessä muiden kanssa. Koko päiväkotityöyhteisöä koskeva toimintatutkimus tarjoisi tähän mahdollisuuden (Venninen 2007, 59). Tutkimuspäiväkodin valintaa varten lähetin kunnan kaikille 14 päiväkodille tiedustelun halukkuudesta osallistua palautteen antamista kehittävään toimintatutkimukseen. Neljä päiväkotia ilmaisi halukkuutensa. Valitsin niistä suurimman ja vanhimman.

Tutkimuksessa hankittiin aineistoa sekä laadullisesti että määrällisesti. Määrällinen aineisto koostui pääosin alku- ja loppukyselystä sekä kuukausittain tiimitovereiden antamasta numeraalisista palautteista. Laadullinen aineisto puolestaan käsitti kuukausittaisten numeroarviointien kirjalliset perustelut, haastattelut, oppimispäiväkirjat ja kirjalliset tehtävät. Prosessin kuvauksessa määrällisen aineiston avulla oli mahdollisuus tuottaa visuaalinen kuva, diagrammi prosessista, mutta ei syytä niille asioille, jotka muutokset olivat aiheuttaneet. Laadullinen aineisto liitti määrälliset kuvaukset kontekstiin ja hankkeessa mukana olleiden henkilöiden subjektiivisiin käsityksiin asioista (Venninen 2007, 64.) Clarke (2004, 81) tuokin esiin, että monimenetelmällisessä tutkimuksessa (mixed methods) molempia metodisia lähestymistapoja voidaan painottaa eri tavoin sen mukaan, mitä tutkimus vaatii.

Toimintatutkimuksen osallistujat olivat laatineet kanssani periaatteet sille, miten palautteen antamista kehittämishankkeen kuluessa arvioidaan. He halusivat, että arviointi suoritetaan sekä numeraa- lisesti että kirjallisesti, sillä eri henkilöille luonnistuvat erilaiset tavat. Olimme yhdessä hioneet numeraalisten arvioiden kuvaukset mahdollisimman yksiselitteisiksi (ks. Venninen 2007, 242). Kirjallisten arvioiden oli tarkoitus tuoda esille konkreettisia esimerkkejä niistä asioista ja tapahtumista, joihin arvio perustui.

Tiimiläiset jakoivat kirjalliset palautteensa toisilleen yhteisissä palavereissaan kerran kuukaudessa, joissa samalla kertoivat sanallisesti papereihin merkitsemänsä asiat. Näin kirjalliset kuvaukset toimivat muistin apuna tilanteissa, joissa kaikki olivat harjoittelijoita ja siksi ainakin osin jännittyneitä. Yhteisenä pyrkimyksenä oli herättää keskustelua palautteiden moninaisuudesta ja sitä kautta tarkastella yhteisen perustehtävän hahmottumista eri henkilöille osin erilaisena. Muiden ajatusten kuunteleminen ja omien ajatusten perusteleminen muodostivat ryhmälle yhteistä tietoisuutta, jonka pohjalta tiimin jäsenet tarkastelivat omaa ja toistensa ammattitaitoa.

Minun tehtäväni ulkopuolisena tutkijana oli palauttaa osallistujille tietyin väliajoin heidän muilta saamansa palautearviot koottuina niin, että he kykenivät näkemään kehittymisensä polun. Jokainen tarkasteli oman kehittymisensä ilmenemistä ja kirjoitti minulle käsityksensä siitä, miten arvosanat kuvasivat hänen omaa käsitystään todellisuudesta.

\section{Prosessit ja niissä syntyvät pyörteet}

Toimintatutkimus on tutkimusta, jossa osallistujat yhteisesti sosiaalisissa tilanteissa pyrkivät parantamaan omia käytäntöjään ja niitä koskevaa ymmärrystään (Carr \& Kemmis 1986, 162). Toimintatutkimuksellisen lähestymistavan valitsin, sillä tähtäsimme kehittämishankkeen avulla muutokseen.

Carrin ja Kemmisin (1986, 203-204) mukaan käytäntö voidaan kohdata teknisen, praktisen tai emansopatorisen toimintatutkimuksn muodossa. Tämä tutkimus sisälsi piirteitä niistä kaikista. Tekninen se oli siksi, että tutkimus käynnistettiin omasta aloitteestani ja itse toimin henkilökunnan kouluttajana sekä tutkimuksen raportoijana. Konsultoijan rooli väistyi toisen syklin aikana, kun henkilökunta alkoi voimaantua asiantuntemuksessaan ja osa siitä siirtyi emansipatorisen tutkimuksen tasolle. Praktisia piirteitä olivat osallistujien tiivis pyrkimys kehittää omaa työskentelyään ja siinä piileviä heikkouksia. Emansipatorisia piirteitä toimintatutkimukseen toi se, että se tähtäsi osallistu- 
jien kykyyn kehittää omaa ja toistensa työtä palautteenannon avulla. Sitä kautta se tähtäsi koko työyhteisön laadun parantamiseen, johon viittasi myös osallistujien halu kantaa vastuuta omasta ja toistensa kehittymisestä. Samoin he kantoivat vastuuta kehittyneempien toimintatapojen siirtämisestä tulevaisuuden toimintaan. (Venninen 2007, 68.)

Tutkijan ja osallistujien suhde vaihtelee toimintatutkimuksesta toiseen. Toimintatutkimuksessa tutkija osallistuu ainakin jollain tasolla tutkittavan kohdeyhteisön elämään. (McNiff \& Whitehead 2006, 29, 34.) Kemmisin (1994) mukaan toimintatutkimus lähtee usein liikkeelle yhden ihmisen ideasta, mutta laajenee sitten suuremman ihmisjoukon yhteiseksi hankkeeksi (Kemmis \& Wilkinson 1998). Greenwood, Whyte ja Harkavy $(1993,176)$ esittävät, että tutkijan kontrolli voi vaihdella jatkumolla, jonka toisessa päässä tutkimuksen kulun kontrolli on kokonaan tutkijalla ja toisessa päässä kysymyksessä on osallistava toimintatutkimus.

Tutkijan roolin dilemma yhtäältä tiedollisena auktoriteettina ja toisaalta tasavertaisena osallistujana on esiintynyt eri tavoin toistuvasti mukana toimintatutkimusta käsittelevässä kirjallisuudessa. (Kuula 2001, 25, 144.) Oma roolini muodostui varsin pian osallistuvaksi toimintatutkijaksi. Koska koulutin kuukausittain henkilökuntaa ja pyrin auttamaan heitä käsitteellistämään erilaisia ilmiöitä, en katsonut alun perinkään voivani toimia pelkkänä fasilitaattorina. Tein tietoisen ratkaisun aktiivisesta roolista, jota myös työyhteisö minulta odotti.

Toimintatutkijana toimin erilaisissa positioissa, joita reflektoin kehittämishankkeen kuluessa. Tutkimuksen alullepanijana ja tiedollisena auktoriteettina koulutuksia toteuttaessani koin ulkopuolisuuden ja erillisyyden roolin osaksi itseäni. Toimintaa koskevaissa päätöksissä ajattelin myös ratkaisujen vaikutuksia tutkimukselleni. Toisaalta tasaväkisenä päätösten toimeenpanijana, kuluneen toiminnan reflektoijana ja tulevan toiminnan suunnittelijana pääsin lähelle osallistujia ja koin itseni yhdeksi heistä. Saman koulutusillan aikana toimin ensin ulkopuolisena kouluttajana, mutta jo kyseisen illan rentoutuhetkellä koin voimakkaasti olevani yksi muiden joukossa. Jälleen, osallistujien antaessa koulutusillan päätteeksi itselleni palautetta sen toteuttamisesta koin itseni osallistujien auktoriteetin alaiseksi. He olivat asiantuntijoita sen suhteen, miten olin onnistunut kyseisen illan kouluttajina. Reflektoin omia tuntemuksiani saadessani suullista julkista palautetta jokaiselta osallistujalta. Haastatellessani osallistujia ja kuunnelles- sani heidän kokemuksiaan toimin tietynlaisessa välimaastossa, en ollut ulkopuolinen, mutta en myöskään osallinen. (Venninen 2007, 72.)

Toimintatutkimusta hahmotellaan usein itsereflektiivisenä kehänä, jossa toiminta, sen havainnointi, reflektointi ja uudelleen suunnittelu seuraavat toisiaan. Ajatus on alkujaan Kurt Lewiniltä (Lewin 1948, 205) ja sitä on kehitelty sittemmin eteenpäin useissa yhteyksissä. Omaan tutkimukseeni spiraalimalli sopi suhteellisen hyvin. Toimintavuosi loi luonnolliset puitteet sykleille, joiden aikana kehittämisen pääpiirteet hahmottuivat. Suuret syklit koostuivat pienistä osasykleistä, joita muokattiin sen mukaan, miten edellinen sykli oli onnistunut.

Tutkimuksessani huomasin, että työyhteisön sisällä syntyi jatkuvasti erilaisia pieniä tapahtumaprosesseja, jotka saattoivat saada alkunsa jostakin näennäisen pienestä asiasta. Ne muotoutuivat erilaisiksi pyörteiksi sen mukaan, miten ne huomioitiin ryhmässä. Pyörteet toimivat ikään kuin pinnan alla tapahtuvina virtauksina, jotka synnyttävät yleisesti havaittavia ilmiöitä kokonaisprosessiin. Samaa ilmiötä Mc Niff (1988, 42-44) kuvaa pääspiraalista irtautuvien sivuspiraalien kautta. Niiden avulla hän ilmentää toimintatutkimuksessa syntyviä spontaaneja tapahtumasarjoja. Syklit muotoutuvat yhä uusiksi ja koko tutkimus on nähtävissä ikään kuin spiraalien spiraalina (McNiff, Lomax, Whitehead 1996, 23).

Pyrin seuraavaksi mallintamaan joitakin tutkimuksessani esiin tulleita kehittämisprosessin aikana havaittuja ilmiöitä. Kuvaan neljän kuvion (vrt. sivuspiraali) avulla osaprosesseja (pyörteitä). Toimintatutkijana suunnittelin jatkotoimenpiteitä osin sen mukaan, minkälaisia vihjeitä havaitsin ympäristöstä.

Yhteinen suunta. Lähtökohtana tutkimuksessani oli, etteivät kaikki kokeneet muutosta tarpeelliseksi. Tutkimuksen alussa jouduimme keskustelemaan, kuuluuko päivähoidon ammatillisuuteen muiden työntekijöiden arvioiminen. Perinteiseen käytäntöön on kuulunut, että henkilökunta saa varsin vapaasti suunnitella ja toteuttaa oman lapsiryhmänsä toimintaa. On vaikea oppia reflektoimaan omaa työtään. Vielä vaativampaa niin taidon kuin rohkeudenkin puolesta on oppia ja uskaltaa arvioimaan työtoverien työtä.

Suorittamassani nimettömässä alkukyselyssä jotkut henkilöt toivat esille, etteivät koe kaikkien olevan sitoutuneita hankkeeseen. Seuraavat kak- 
si lainausta kuvaavat asennetta, jonka muuttaminen tuli vaatimaan asianomaisilta rohkeaa omien ajattelumallien reflektointia.

En voi antaa numeroa, en arvostele työntekijöitä. Aika on mennyt ryhmän lapsiin.

(palautteenantoarvio itselle kehittämishankkeen alussa tammikuussa 2003)

Tuntuu, että aikaa \& voimavarjoja palautteen antamiseen ei riitä. Edelleen olo on myös "elä ja anna toistenkin elää" - eli jokainen tekee työnsä tavallaan ja en näe tarvetta antaa palautetta. (elokuussa aloittaneen työntekijän palautteenantoarvio itselle lokakuussa 2003)

Henkilökunnan huomion "kaikki eivät ole hankkeeseen sitoutuneita” pohjalta ymmärsin, että olisi tärkeää käsitellä yhdessä jokaisen osallistujan hanketta kohtaan tuntemat pelot ja odotukset (ennakko-oletusten käsittelyn tärkeys). Työyhteisön jäsenet olivat kokeneet kukin tahoillaan asioita, jotka samaistivat tähänkin tutkimukseen. Aiemmat kokemukset loivat ensimmäiset kiinnityskohdat, ennakko-oletukset, henkilökohtaisille suhtautumisille uutta kehittämishanketta kohtaan. Päädyin toteuttamaan heti tutkimuksen aluksi "skenaariotyöskentelyn”. Kävi ilmi, että ennakko-oletukset olivat sekä positiivisia että negatiivisia.

- selän takana puhuminen vähenee / poistuu

- ymmärtäisimme, että se on välttämätön osa työtämme

- tunne, että kaikki on turhaa ajanhaaskausta, yritys antaa palautetta tuottaisi lisää työtä - "palautekeskustelut” päättyisivät syytöksiin ja riitaan

Nostammalla nimettöminä esitetyt ennakko-oletukset esille ja käsiteltäviksi pyrin rakentamaan osallistujille luottamusta siihen, että heidän kokemuksillaan olisi merkitystä tutkimuksen kehittämiselle. Positiivisten skenaarioiden pohjalta muodostimme kehittämishankkeelle "yhteisen vision".

Tiedämme, etä meidän jokaisen velvollisuus on kehittää omaa ammattitaitoamme. Jotta voisimme tässä onnistua, on meidän saatava selville ne asiat, jotka vaativat kehittymistä. Siinä voimme auttaa toinen toistamme tarkastelemalla yhdessä työskentelyämme ja jakamalla siitä palautetta.

Jotta kehittyisimme tässä tehtävässä, on meidän haluttava ja uskallettava luottaa toinen toisiimme, kannustettava toisiamme ja ymmärrettävä, että jokainen antaa palautetta omalla tyylillään ja haluaa vastaanottaa sitä myös itselleen sopivalla tavalla.

Näin luomme avoimen ja turvallisen ilmapiirin, jossa uskallamme harjoitella yhdessä sovittujen sopimusten mukaan. Irrottaudumme tietoisesti epäsuorasta palautteesta, sillä tavoitteenamme on auttaa toinen toistamme.

Kun jaksamme sitkeästi yrittää aluksi teennäiseltäkin tuntuvia asioita, totumme uuteen työtapaamme ja osaamme arvostaa itseämme uusien tietoisuuteemme tulevien taitojen pohjalta.

Negatiivisista skenaarioista kävimme yhteistä keskustelua ja sovimme, että osallistujien kokemuksia seurattaisiin tiiviisti ja niiden pohjalta tehtäisiin yhteisiä ratkaisuja. Tämä laukaisi jännitystä. (Venninen 2007, 180-181.) Seuraavat arviot työntekijät antoivat kolme kuukautta kehittämishankkeen alkamisen jälkeen.

On ollut kiva huomata kehitys työkavereissa. Itselleni on edelleen vaikeaa antaa rakentavaa palautetta. Palautetta on välillä vaikea ottaa vastaan, kun palautteen antaja näkee minut hyvin eri tavalla kuin minä itse.

(väliarviointi ensimmäisen syklin aikana)

Palautteen antaminen varsinkin negatiivisista asioista on helpottunut, ehkä siksi, että kaikki hakevat palautetta aktiivisemmin. Omaa palautteen vastaanottamista on joutunut pohtimaan, vaikka ei palautteen vastaanotto ole niin vaikeaa kuin antaminen. On joutunut miettimään omia käyttäytymismalleja ja keskittymään niihin. Omasta itsestä auennut lisää puolia. (väliarviointi ensimmäisen syklin aikana)

Seuraavassa kuviossa (kuvio 1 sivulla 18) on esimerkki siitä, miten pyrin vahvistamaan sitoutumista hankkeeseen. (Venninen 2007, 180.) Kun yhteistä suuntaa luotsataan, on hyvä, jos lähtökohtana on osallistujien oma historia. Kun huomiota kiinnitetään jokaisen työntekijän esille nostamiin asioihin, he saavat mahdollisuuden sitoutua henkilökohtaisesti uuteen hankkeeseen.

\section{Ympäristö muovaa kosken uoman}

Hyvä nykyhetki. Kontekstin merkitystä on painotettu ammattitaidon kehittymistä koskevissa tutkimuksissa jo pitkään (esim. Eteläpelto 1997, 97). Kontekstin merkitys tässä tutkimuksessa tuli esille erilaisina työympäristöstä johtuvina ilmiöinä, henkilöstöön joko yksittäisinä henkilöominaisuuksina tai vuorovaikutukseen liittyvinä ilmiöinä sekä 


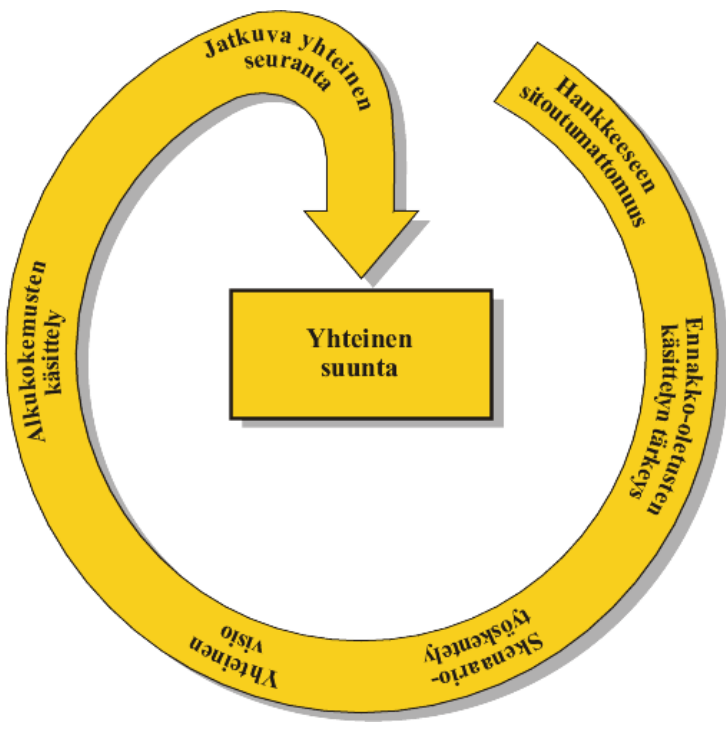

Kuvio 1. Kehittämishankkeeseen sitoutumattomuuden aiheuttamia toimintoja. YHTEINEN SUUNTA: hankkeeseen sitoutumattomuus > ennakko-odotusten käsittelyn tärkeys > skenaariotyöskentely > yhteinen visio > alkukokemusten käsitely > jatkuva yhteinen seuranta

itse substanssiosaamisen ominaisuuksina. Perustehtävä hahmottuu osin sellaisina ominaisuuksina, joihin ei ole olemassa yhtä oikeaa ratkaisua (esimerkiksi erilaiset kasvatustilanteet). Suuri vastuu lapsista ja toiminnan hektisyys asettavat haasteita vuorovaikutukselle, varsinkin, kun lukuisia vuorovaikutussuhteita on kyettävä hoitamaan samanaikaisesti työtovereiden, lasten ja heidän vanhempiensa kanssa. Päiväkodissa on vain harvoja hetkiä, jolloin koko henkilökunta voi kokoontua keskustelemaan yhdessä ilman vastuuta lapsista. Työntekijöiden huomion on lisäksi oltava jatkuvasti lapsissa, jolloin on vaikea keskittyä hoitamaan asioita työtovereiden kanssa. Tutkimukseen osallistuneen työntekijän kuvaus osoittaa sen hyvin. (Venninen 2007, 179.)

...Oli kiva kuulla palautetta, jota haluan enemmän mutta ajoitus ei ollut paras mahdollinen. Lapset "hilluivat" vieressä ja oli kovin kiireen tuntua. (Tarjan päiväkirjamerkintä keväällä 2003)

Kokouksissa saatu informaatio perustuu usein edustajan kautta saatuun toisen käden tietoon, joka lisää väärinymmärrysten riskiä. Vuorovaikutusta koskevat vaikeudet tekevät ymmärrettäväksi, että konfliktit muodostuvat väistämättömäksi osaksi päiväkotityötä, joka koostuu suurimmaksi osaksi työskentelystä erilaisten ihmisten kanssa. Niiden käsittely ja ratkaisu muodostuvat tärkeiksi asioiksi. (Rodd 2004, 38, 49, 61-65.) Seuraavissa lainauksissa työntekijät kuvaavat konflikteja synnyttävää maaperää.

Naristaan selän takana, eikä tulla sanomaan suoraan. Peiliin pitäisi välillä kattoo.

(Tarjan päiväkirjamerkintä tutkimuksen alussa).

Meil oli hyvä keskustelu Tarjan ja mun erilaisuudesta ja meidän kompastuskivistä. Minä kun olen tunne- ja Tarja järki-ihminen, niin siinä palautteen annossa aina sattuu ja tapahtuu. Tarjaa tuntuu ärsyttävän mun tuneellisuus ja mua Tarjan kovuus.

(Liisan päiväkirjamerkintä keväällä 2003)

Työskentely-ympäristön ominaispiirteet eivät yksin ratkaise, onko kehittämistyötä helppoa vai vaikeaa tehdä. Myös tiimin sisällä vallitsevalla kulttuurilla on suuri merkitys. Kulttuurisen säännöstön toimintaa muovaamaa työyhteisöä Wenger (1998) kutsuu käytäntöyhteisöksi (community of practice). Oppiminen nähdään silloin sosiaalisena tapahtumana, jossa ihmiset osallistuvat aktiivisesti yhteisöjensä käytäntöihin. (Wenger 1998, 4.) Päiväkodissa tiimien voidaan katsoa muodostavan käytäntöyhteisöjä, joiden sisäiset keskustelut rakentavat yhteistä ymmärrystä. Se sitouttaa jäseniä yhteiseen toimintaan herättäen halua oppia toisiltaan (Karila \& Nummenmaa 2006, 44, 46). Palautteen jakamisen harjoittelu pohjautui tiimin jäsenten jakamaan käsitykseen tiimikollegoiden yhteisvastuusta toistensa ammatillisessa kehittämisessä.

Palautekulttuurin edistävä tai heikentävä vaikutus ilmeni siis monin tavoin. Jos palautekulttuuri oli suotuisa, kollegat tiedostivat esimerkiksi toistensa erilaisuuden ja osasivat arvostaa sitä. Kehitystä heikentävä palautekulttuuri saattoi ilmetä esimerkiksi vierautena työntekijöiden välillä, jännitteinä tai vastavuoroisuuden puutteena. $\mathrm{Pa}$ lautetaitojen kehittyminen oli sidoksissa myös muihin kontekstuaalisiin tekijöihin. Esimerkiksi työsuhteiden loppumisesta aiheutui mielipahaa, joka heikensi koko tiimin jäsenten motivaatiota. (Venninen 2007, 178.)

Sit kevät tuli vähän siinä et tiedettiin et Jaskalta loppuu työt ..., siinä vaiheessa hän löi jarrut vähän kehiin eikä enää ollut sitä haluakaan kehittää itteään ja miettiä näitä asioita. (loppuhaastattelu)

Kävi ilmi, että ryhmän suotuisasta kulttuurista huolimatta kehitys ei päässyt hyvin käyntiin, en- 
nen kuin ryhmän jäsenet tunsivat toisensa. Tuttuus vapautti energiaa uusien taitojen harjoittelulle. (Venninen 2007, 177.) Katzenbach ja Smith $(1993,185)$ tuovatkin esiin, että uudet jäsenet merkitsevät kaksinaista haastetta: tiimin on otettava vastaan tuore näkökulma ja tulijan on ansaittava paikkansa tiimissä. Uuden jäsenen ongelma on monitahoinen. Hän on muiden jäsenten tapaan vastuussa tehdyistä päätöksistä, joten ellei tiimi anna hänelle liikkumavaraa kyseenalaistaa asioita ja jakaa riskejä, se rajaa uuden jäsenen mahdollisuuksia toimia täysivertaisena jäsenenä. (Kts. myös Nivala 2000, 28.)

Olet juuri aloittanut ryhmässämme ja aika on mennyt tutustumiseen ja opetteluun, itsekin olen vasta muutaman kuukauden ollut töissä ja en ole velä sinut palautteen annon ja vastaanottamisen kanssa. (palautteenantoarvio syyskuussa 2003)

Uuden työparin kanssa haetaan vasta yhteistä työtapaa, toisaalta tilanne on avoin yhteisen linjan löytämiseksi ja voi puhua avoimesti. (palautteenantoarvio syyskuussa 2003)

Pyrin huomioimaan työskentely-ympäristön erityisolemuksen ja lisäämään osallistujien ammatillista tietoisuutta esimerkiksi varhaiskasvatustyössä tarvittavaan osaamiseen liittyvien koulutusiltojen

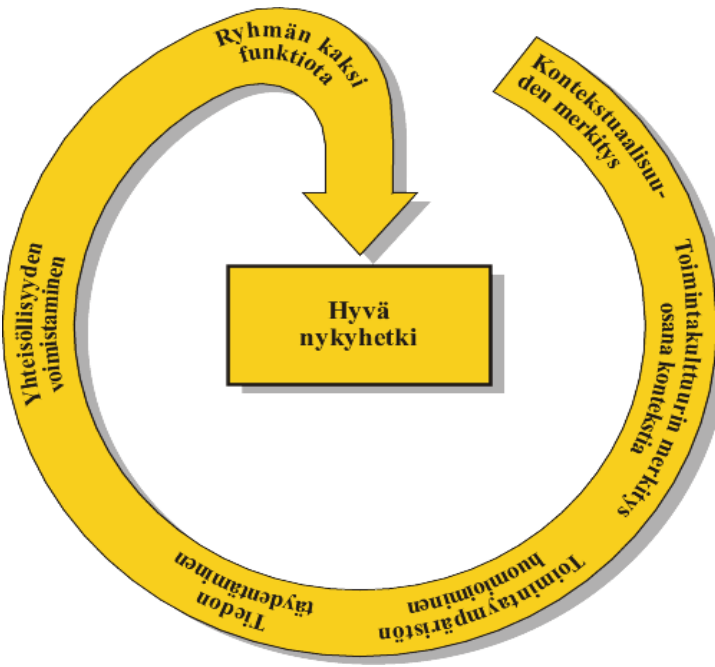

Kuvio 2. Kontekstuaalisuuden merkityksen huomioiminen tiimin hyvän nykyhetken muodostumisessa. HYVÄÄ NYKYHETKI: kontekstuaalisuuden merkitys $>$ toimintakulttuurin merkitys osana kontekstia > toimintaympäristön huomioiminen > tiedon täydentäminen > yhteisöllisyyden voimistaminen > ryhmän kaksi funktiota. avulla. Pyrin myös tukemaan yhteisöllisyyden voimistumista koulutukseen sisältyvien yhteisten rentoutushetkien avulla. Hankkeen edetessä tuli esiin tiimin kaksoisfunktio. Tiimin tehokkaaseen työksentelyyn ei riitä vain sen jäsenten korkea yksilöllinen osaaminen. Yhtä tärkeää on sen jäsenten kyky puhaltaa yhteen hiileen. (Venninen 2007, 181.)

Jotta tiimissä voitaisiin työskennellä työtä tukevassa ilmapiirissä (hyvä nykyhetki), on tärkeää pyrkiä kehittämään sekä tiimiläisten osaamista että kykyä työskennellä yhdessä.

\section{Koskenlaskijoiden välille syntyy jännnitteitä}

Jännitteiden syntyminen. Henkilöt erosivat toisistaan esimerkiksi luonteenpiirteiden tai toimintatapojen suhteen ja ilmaisivat käsityksensä persoonallisesti. He saattoivat ymmärtää toisiaan väärin eivätkä aina ehtineet, osanneet tai edes halunneet korjata väärinkäsityksiään. Tällaisia tilanteita syntyi eri tiimien, tiimien ja johtajan sekä tiimin jäsenten välille. (Venninen 2007, 181-182.)

Henkilöt reagoivat tunnetasolla hyvin persoona- ja kulttuurikohtaisesti ja ilmensivät itseään myös käyttämällä vallankäytön erilaisia muotoja. Sen myötä ongelma laajeni koskettamaan koko tiimiä. Se sai aikaan osittaista perustehtävästä syrjäytymistä, koska se kulutti runsaasti energiaa, jota olisi tarvittu tiimin työn suorittamiseen. (Venninen 2007, 182.) Seuraavissa esimerkeissä konfliktin osapuolet kuvaavat tilannettaan omien näkemystensä mukaan.

Me emme onnistu tässä! Tää palautteen anto meidän kahden (Tarjan ja mun) kanssa ei onnistu! Ei voi olla tarkotus, että toisia satutetaan koko ajan, siihen mä en suostu!!! Mulla on tosi paska olo, mä voin henkisesti ja fyysisesti huonosti. (Liisan päiväkirja)

Koin ihan selvästi, että vaikka yritin miten paljon tahansa antaa palauteta, numeroni pysyi samassa, vaikka palautelapussa olisikin näkynyt edistys. Kuulin jopa työtiimin jäseniltä, että olivat keskustelleet, minkä numeron antavat minulle! Kaiken seurauksena oma innostukseni laantui.(Tarjan päiväkirja)

Seuraavassa kuviossa (kuvio 3) kuvaan tiimissä ilmenevien jännitteiden syntymistä ja niiden vaikutuksia toimintaan. Jännitteiden ilmeneminen 


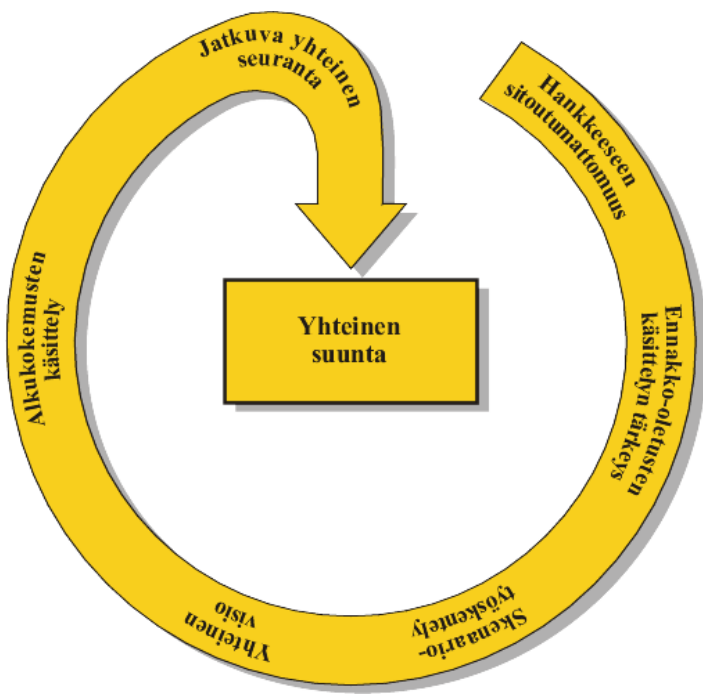

Kuvio 3. Henkilöiden erilaisuuden synnyttämien jännitteiden ilmeneminen tiimissä. JÄNNITTEIDEN ILMENEMINEN: henkilöiden erilaisuus > henkilöristiriidat > ympäristön vaikutukset ristiriitojen kohtaamiseen > tunteiden merkitys osallisten käyttäytymiseen > vallankäytön ilmeneminen > perustehtävän sivuuttaminen

osoittautui tutkimuksen kuluessa olevan kehittämishankkeeseen kuuluvaa tapahtumaa. Konfliktit ryhmän sisällä osoittautuivat kuitenkin energiaa vieviksi ja vähensivät sitoutumista palautteen antamiseen. Tulosten perusteella vaikuttaa siltä, että tiimien ilmapiiriin ja henkilösuhteisiin liittyvät asiat korostuvat lähdettäessä yhteiseen kehittämishankkeeseen. Jännitteiden hallinta muodostuikin tämän tutkimuksen mukaan erityisen olennaiseksi asiaksi, kun pyritään kehittämään toimintaa yhdessä. (Venninen 2007, 182-183.)

Mut sittehän me pidettiin yks ilta nyt keväällä mis jokainen puhu omat tunteensa et mitä oli tunteita tän vuoden aikana tullu, se puhdisti mun mielestä sen tilanteen hyvin. Vaikka se oli aika rankka ilta...mut se autto paljo yhteishenkee ja puhdisti ilmaa. Siin tuli aika tiukkaakin kahen ihmisen välille mutta ne puhu sen asian sitte jälkeenpäin ja se oli ihan ok, eikä siihen muut puuttunut enää.

(loppuhaastattelu)

Uskalsin rehellisesti myöntää pelkääväni antaa palautetta hänelle ja toivoin myös, että tästä lähin on aina kolmas henkilö paikalla, kun annamme rakentavaa palautetta, jotta pysyisimme asiassa. Hän oli samaa mieltä ja myönsi, että vihaisena tulee kaivettua kaikki vanhat ongelmat esiin... (Liisan päiväkirja)
Jännitteiden hallinta. Tarkentamalla erilaisia tavoitteita rajasimme myös mahdollisuuksia käyttää valtaa väärin. Pyrin koulutusten avulla kehittämään työyhteisön jäsenten yhteistyö- ja vuorovaikutusosaamiseen liittyviä taitoja. Pyrkimyksenäni oli vahvistaa ryhmän kykyä toimia yhdessä ja tarkastella siinä ilmenevää ammatillisuutta yksilöä laajemmassa perspektiivissä. (Venninen 2007, 183.) Seuraavassa kuviossa (kuvio 4) on kuvattu asioita, joiden merkitys osoittautui korostuvan, kun pyrimme hallitsemaan erilaisia jännitteitä.

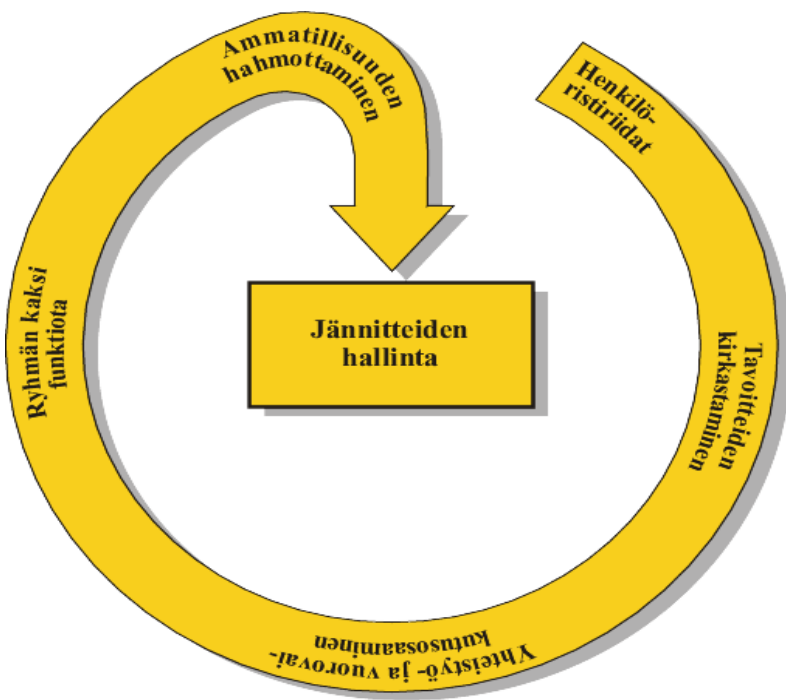

Kuvio 4. Henkilöristiriitojen aiheuttamien jännitteiden hallintaan tähtääviä toimintoja tiimissä. JÄNNITTEIDEN HALLINTA: henkilöristiriidat > tavoitteiden kirkastaminen > yhteisö- ja vuorovaikutusosaaminen > ryhmän kaksi funktiota > ammatillisuuden hahmottaminen.

Toimintatutkimuksen sisällä oli käynnissä samanaikaisesti monia erilaisia prosesseja, jotka nivoutuivat toisiinsa eri tavoin ja toimivat jatkuvassa vuorovaikutuksessa myös keskenään. Sama ilmiö saattoi olla osallisena useissa eri prosesseissa. Koko kehittämishankkeen tarkoituksenamme ja lähtökohtanamme oli yhteinen pyrkimys samaa päämäärää kohti (yhteinen suunta). Yhteisenä kehittämishankkeen päämääränämme oli oppia jakamaan työtovereille ammatillista palautetta ja sen avulla tukea heidän kehittymistään työssään. Hyvän päämäärän saavuttamiseksi tuli huolehtia siitä, että nykyhetki olisi sille suotuisa (hyvä nykyhetki). Tätä tuki tiimin jäsenten yhteinen innostunut paneutuminen toiminnan kehittämiseen. $\mathrm{Ny}$ kyhetkessä ilmeni jännitteitä, joiden hallinta muodostui yhteisen kehittämisen kannalta ratkaisevan tärkeäksi. (Venninen 2007, 183-185.) 
Kokonaisprosessin erilaiset osat painottuivat eri tilanteista ja tapahtumista johtuen eri tavoin. Esimerkiksi kehittämishankkeen alussa painottui yhteisen suunnan etsintä, mutta se vaikutti myös koko prosessin ajan. Jännitteiden hallinta oli hyvä huomioida ennakoivasti erilaisia ratkaisuja tehtäessä, mutta toimintana se painottui erityisesti, kun konflikteja ilmeni. (Venninen 2007, 185.)

Kun uusi työntekijä tuli tiimiin, painottui jäsenten toiminnassa yhteisen suunnan etsintä. Kollega pyrittiin perehdyttämään vakiintuneisiin tiimikäytäntöihin. Samalla tavoiteltiin hyvää nykyhetkeä. Uuden jäsenen tulo aiheutti myös jännitteitä, joita pyrittiin hallitsemaan joko tietoisesti tai tiedostamatta. Tämä kävi ilmi useimmissa tiimeissä, kun vaihtuneet työntekijät aloittivat työt. Kun tiimistä oli työntekijä lähdössä pois, sekä tiimillä että kyseisellä työntekijällä oli oma suuntansa, jolloin yhteisen suunnan etsiminen menetti merkityksensä. Se herätti kuitenkin jännitteitä työntekijöiden välille ja jos niitä ei kyetty hallitsemaan, ei hyvä nykyhetki voinut toteutua. Jos työntekijät osasivat suhtautua tilanteeseen rakentavalla tavalla, he voivat kokea tilanteen haikeana, mutta antoisana yhteisen kokemuksen läpikäymisenä. (Venninen 2007, 185.)

Tässä kuvatussa tutkimuksessa toimintatutkimuksen kokonaisprosessin vauhti ei pysynyt samana, vaan se vaihteli jatkuvasti tilanteista johtuen. Palattaessa koski-metaforaan voisi ajatella, että työyhteisön jäsenet ja tiimit laskivat koskea vaihtelevilla nopeuksilla. Kivikot saattoivat heittää kanootit vastavirtaan, josta mukanaolijat selvittivät ne useimmiten uudelleen yrittämällä jatkamaan matkaa. Vaatteiden kastuessa toiset kiristivät hampaansa yhteen ja päättivät pyrkiä parempaan, toisille olisi riittänyt kiertäminen rannan kautta.

\section{Perillä vai välietapilla?}

Palautteet jaottelin karkeasti kolmeen ryhmään sen mukaan, miten ne ilmenivät ja missä määrin vastaanottajan oli mahdollista niistä hyötyä. Ne olivat kehittävä, toteava ja myötäävä / estävä palaute. Tätä varten analysoin koko aineistosta palautteita koskevat maininnat. Pelkistetyt kuvaukset autenttisista lainauksista ryhmittelin perusomainaisuuksien mukaan kymmeneen alaluokkaan ja ne edelleen neljään yläluokkaan, jotka kuvasivat palautteen antajan suhtautumista tehtäväänsä. Kehittävää palautetta kuvastaa vastapuolen tilanteeseen paneutuminen (asiaan paneutuminen, konkreettisuus, rohkeus, sitkeys, kannustaminen, tasapuolisuus, ammatillisuus ja yksilöllisyys). Toteavaa palautetta kuvastaa pintapuolinen asiaan paneutuminen (mielipiteen kätkeminen esimerkiksi "rivien väliin" tai spontaani reagointi). Myötäävää/estävää palautetta kuvastaa sivusta seuraaminen (myötäeläminen vastapuolen kanssa tai passiivinen vastarinta). Taitava palautteen antaja jakoi runsaasti kehittävää palautetta, jonka olennainen piirre on sen kyky synnyttää keskustelua.

Hankamäki (2004) painottaa, että paljon informaatiota sisältävä lause voi tulla ymmärretyksi vain yhdellä tavalla. Vähän informaatiota sisältävä voidaan ymmärtää usealla tavalla (Hankamäki 2004, 166.). Palautteessa vähän informaatiota sisältää esimerkiksi kuvaus "Ihan hyvä”. Paljon informaatiota sisältää kuvaus "Huomasitko, kun käytit...näkemäni perusteella se selvästi vaikutti...”. Harjoitellen lienee mahdollista kehittää toteavasta tai myötävästä palautteesta lisäinformaation avulla kehittävää palautetta. Esimerkiksi toteavaksi palautteeksi määrittelemäni "Asia hoidettu hyvin” palautteen voisi muuttaa kehittäväksi lisäämällä siihen kuvauksen, millä tavoin asia on hoidettu hyvin. Kuka teki mitäkin? Miltä tilanne sivustaseuraajan silmissä vaikutti?

Tarkastelin tutkimuksessani palautetaitojen kehittymistä myös neljän ammatillisen tason kautta, joihin jaottelin palautearviot niiden numeraalisten arvioiden perusteella. Arvion perustana olevat kirjalliset tekstit analysoin, ja löysin kutakin osaamistasoa kuvaavia yhteisiä piirteitä. Esimerkiksi tunteet ilmenevät palautetilanteissa eri tavoin. Kun henkilö on palautteen jakajana ammatillisen vasta-alkajan tasolla, tunteet hallitsevat palautetilanteessa työntekijää eikä päinvastoin. Pelko saattaa estää palautteen antamisen tai suuttumus tai lamaannus saadun palautteen käsittelemisen. Ammatillisella perustasolla työntekijä hallitsee yleensä tunteensa palautetilanteessa, mutta odottamattomassa tilanteessa taito voi rakoilla. Ammatillisen kypsyyden tasolla omat tunteet hallitaan yleensä erinomaisesti. Voi ajatella, että työntekijä osaa keskustella ammatillisella tasolla erilaisten palautetilanteiden synnyttämistä tunteista, eritellä ja analysoida niitä. Ammatillisella esperttitasolla henkilö kykenee hyödyntämään palautteessaan tunteita. Esimerkiksi hän voi keventää tunnelmaa huumorin avulla. Palautteen jakamisen ja vastaanottamisen taidot kehittyivät puolentoista vuoden aikana keskimäärin yhden ammatillisen tason verran (ks. Hersey ja Blanchard 1988; Hersey, Blanc- 
hard ja Johnson 2001).

Analyysin avulla kävi ilmi, että tunteiden lisäksi tietyt muutkin asiat korostuivat palautteen antamista ja vastaaottamista koskevan harjoittelun ja kehittymisen eri vaiheissa. Tällaisia olivat:

- palautteen määrä ja tasapuolisuus sitä jaettaessa

- tilanteiden valinta, joissa palautetta annettiin ja tapa jakaa palautetta

- tapa ottaa palautetta vastaan ja halu antaa vastavuoroisesti saadusta palautteesta palautetta

- asiat, joihin annettu palaute perustui

- palautteen antamiseen rohkaiseminen

- palautteen antamisen sulautuminen kunkin persoonalliseen ammattitaitoon

Palautteen vastaanottamisen merkitys korostui lähes heti, kun palautetta ryhdyttiin aktiivisesti jakamaan. Oli helpompaa kehittyä hyväksi palautteen antajaksi, jos vastapuolella samaan aikaan oli halu oppia vastaanottamaan sitä mahdollisimman taitavasti. Tutkimukseni tuki Leskelän (2005, 244 245) tutkimusta, jossa hän havaitsi, että mentoroinnin onnistuminen vaati myös vastapuolen, aktorin, aktiivisuutta.

Samoin työyhteisön kyky kantaa vastuuta kehittämishankkeen onnistumisesta eteni pääpiirteissään saman kaavan mukaan. Loppuarvioinneissa kävi ilmi, että osallistujat kokivat hyväksi oman roolinsa ja tutkijan roolin muuttumisen vastakkaisiksi. Aluksi tutkija kantoi asioista suuren vastuun, kehittämishankkeen loppuessa osallistujat olivat tottuneita kasvaneeseen vastuuseensa ja pystyivät loppumetreillä irrottautumaan tutkijan ohjauksesta kokonaan.

Palautetaitojen kehittäminen ei ole turhaa, sen on oman tutkimukseni lisäksi moni muukin tutkimus osoittanut. Patri (2002) tutki vertaispalautteen mahdollisuuksia kiinalaisten yliopisto-opiskelijoiden suullisen ilmaisutaidon kehittämisessä. Tutkimus osoitti, että toveripalaute voi toimia yhtä tehokkaana arviointimuotona kuin opettajan antama palaute edellyttäen, että arviointikriteerit ovat selkeät. (Patri 2002, 125-126.) Omassa tutkimuksessanikin korostui yhteisten arviointikriteerien merkitys.

Samantapaisiin johtopäätöksiin pääsivät myös Berg, Admiraal ja Pilot (2003), jotka tutkivat vertaispalautteen mahdollisuuksia Alankomaiden korkeakouluopiskelijoiden keskuudessa. Lisäksi he painottivat, että palautetta annettaessa yhdistel- mä kirjallisesta ja suullisesta palautteesta on hyödyllinen, jolloin jälkimmäinen voi selittää edellistä.

Omassa tutkimuksessani kävi myös ilmi, että yhdistelmä numeraalista ja kirjallista palautetta on hyödyllistä. Koen, että kvalitatiivinen ja kvantitatiivinen aineisto tukivat toisiaan voimakkaasti. Niiden avulla kykenin itsekin tarkastelemaan aineistoa eri lähtökohdista ja sain myös vastauksia erilaisiin asioihin. Esimerkiksi palautekäyrien tarkastelu visuaalisesti kaipasi tuekseen selittäviä kuvauksia, jotka nekään eivät yksin olisi luoneet havainnollista kuvaa. Loppuarvioinneissa osallistujien mieltymykset kummankin arviointitavan käyttämiseen menivät jokseenkin tasan. Silti he kokivat, että oli hyvä joutua miettimään asiaa myös itselle vieraammalla tavalla.

\section{Uudelle koskelle paremmin varustein}

Joki jatkaa matkaansa. Suvannon jälkeen joesta haarautuu pieni uoma. Se on toimintatutkijan oma reitti, joka saattaa viedä hänet uusille erilaisille koskille. Ennen muista eroamista on syytä yhdessä arvioida, mitä seuraavilla koskenlaskuilla olisi hyvä huomioida.

Toimintatutkimus on aina sen toteuttajien yhteinen matka. Kuten kaikille matkoille, siihenkin on kannattaa varautua mahdollisimman hyvin. Lewin (1974) tuo esille voimakenttäanalyysin mahdollisuudet muutoksen ohjaamisessa. Sen kautta voidaan arvioida muutokseen sisältyviä erilaisia voimia (muutosta edistävät tai vastustavat voimat) ja niiden vaikutuksia. Kun muutosta vastustavat voimat on eritelty ja analysoitu, voidaan muutoksen ohjauksessa keskittyä niihin asioihin, joihin on mahdollista vaikuttaa. Voidaan pyrkiä joko vahvistamaan muutosta edistäviä voimia tai heikentämään muutosta vastustavia voimia ja sitä kautta tukea muutoksen etenemistä.

Jos olisin tutustunut Lewinin voimakenttäanalyysiin ennen oman tutkimukseni kenttäosuutta, olisin hyödyntänyt sen suomia mahdollisuuksia jo tutkimuksen alussa. Olisin saanut siitä apua skenaariotyöskentelyn toteuttamisessa, kun analysoimme yhdessä toimintatutkimuksen etenemistä. Se olisi tarjonnut konkreettisen apuvälineen, jonka avulla työyhteisön jäsenet olisivat voineet havainnollistaa erilaisia ilmiöitä. Monet kehittämisprosessille tyypilliset piirteet olisi yhdessä voitu ennakoida ja arvioida. Niiden analysointi olisi myö- 
hemmin ollut luontevaa, olisimmehan ennakoineet jotain sellaista tapahtuvaksikin. Tätä kautta työyhteisön jäsenet saisivat mahdollisuuden tuntea, että voivat edes jollain tasolla ennakoida muuttuvaa tulevaisuutta.

Toimintatutkimuksen loppumetreillä jäimme miettimään, kuinka oleellinen merkitys palautteen annossa on hyvillä kysymyksillä, sellaisilla, jotka pistävät vastapuolen pohtimaan syitä toimintaansa. Hakkarainen, Lonka ja Lipponen (2004, 189, 280-282) sekä Jalava (2001, 109) ovat kaikki tuoneet esille tilannetta lukitsevien tai syventävien kysymysten erilaiset olemukset. Seuraava vastaava tutkimus olisikin antoisaa toteuttaa erityisesti kysymyksenasetteluihin paneutuen.

Kokonaisuutena voisin sanoa, että työyhteisön kehittäminen on kuin koskenlaskua. Matkaan lähdetään intoa uhkuen, välillä joudutaan pelottaviin karikoihin ja joskus saadaan nauttia rauhallisista suvantopaikoista. Jotkut pelästyvät ensimmäisestä kanootin pohjakosketuksesta, toisille se on vasta alkuverryttelyä. Perille tullaan enemmän tai vähemmän rähjääntyneessä kunnossa. Matkaa olisi antoisinta tehdä niin, että kaikki nauttisivat, oppisivat ja haluaisivat lähteä yhdessä yhä uusille koskille.

\section{Lähteet}

Clarke, D.D. (2004). Structured judgement methods - the best of both words? Teoksessa Z . Todd, B., Nerlich, S., McKeown \& D. D. Clarke (toim.) Mixing methods in psychology. The integration of qualitative and quantitative methods in theory and practice, 80-100. New York: Psychology Press.

Eteläpelto, A. (1997). Asiantuntijuuden muutuvat määritykset. Teoksessa J. Kirjonen, P. Remes \& A. Eteläpelto (toim.) Muuttuva asiantuntijuus. Jyväskylän yliopisto. Koulutuksen tutkimuslaitos, 6-102.

Eteläpelto, A. \& Rasku-Puttonen, H. (1999). Projektioppimisen haasteet ja mahdollisuudet. Teoksessa A. Eteläpelto \& P. Tynjälä (toim.) Oppiminen ja asiantuntijuus. Työelämän ja koulutuksen näkökulmia. 1-2. painos. Helsinki. WSOY, 181-205.

Hankamäki, J. (2004). Dialoginen filosofia: teoria, metodi ja politiikka. Yliopistopaino.
Hakkarainen, K., Lonka, K. \& Lipponen, L. (2004). Tutkiva oppiminen. Järki, tunteet ja kulttuuri oppimisen synnyttäjinä. 6. uusittu painos. Helsinki: WSOY.

Hersey,P., Blanchard, K. \& Johnson, D. (2001). Management of Organizational Behavior. Leading Human Resources. 8. pianos. New Jersey: Prentice-Hall.

Jalava, U. (2001). Esimiestyö - valmentaminen ja uudistuminen. Helsinki: Tammi.

Juuti, P. \& Vuorela, A. (2002). Johtaminen ja työyhteisön hyvinvointi. Aavaranta-sarja n:o 51. Jyväskylä: PS-kustannus.

Karila, K., Nummenmaa, A. R. (2001). Matkalla moniammatillisuuteen. Kuvauskohteena päiväkoti. Helsinki: WSOY.

Katzenbach, J. R. \& Smith, D. K. (1993). Tiimit ja tuloksekas yritys. Suom. M. Tillman. Espoo: Weilin + Göös.

Keskinen. S. (2005). Alaistaito. Luottamus, sitoutuminen, ja sopimus. Kunnallisalan kehittämissäätiön Polemia-sarjan julkaisu n:o 59.

Leskelä, J. (2005). Mentorointi aikuisopisekelijan ammatillisen kehittymisen tukena. Tampereen yliopisto. Acta Univesitatis Tamperensis 1090.

Lewin, K. (1974). Frontiers in group dynamics: concept, method, and reality in social science; social equilibria and socia change. Human Relations 1(1) (June 1974), 5-41.

McNiff,J., Lomax,P. \& Whitehead,J. (1996). You and your action research project. London: Routledge.

Rodd, J. (1994 / 2004). Leadership in early childhood. The pathway to professionalism (2.pain.) UK: Open university press.

Venninen, T. (2007). ”Olen enemmän alkanut pohtimaan ja sanomaan ääneen mitä ajattelen" - ammatillinen kehittyminen ja yhteisöllinen palaute päiväkodin työtiimeissä. Helsingin yliopiston soveltavan kasvatustieteen laitos. Tutkimuksia 282.

Wenger, E. (1998). Communities of practice. Learning, meaning and identity. Cambridge: Cambridge University Press. 